\title{
DOC. ING. IVAN HERČKO, CSC. - JEHO PRÍNOS PRE MUZEOLÓGIU AKO VEDU
}

ELENA HEGYI

Všestranný a uznávaný odborník $s$ bohatou publikačnou činnostou sa vo svojej vedecko-výskumnej činnosti takmer 40 rokov systematicky venoval montánnej histórii s dôrazom na región Slovenska, predovšetkým dejinám geologických vied, banskej techniky a baníckeho školstva na Slovensku. Výsledky svojho doterajšieho výskumu Ivan Herčko postupne spracoval do komplexných vedeckých a populárno-vedeckých monografií, ktorými sprístupňuje výsledky vedeckého výskumu v oblasti dejín geológie, baníctva, banskej techniky a baníckeho školstva na Slovensku.

Analytickým spracovaním materiálov predovšetkým z jeho súkromného archívu, terénnym výskumom a oral history bolo možné priblížit túto osobnost'. Podstatou článku je poukázat na významné myšlienky a prínosy, ktorými sa zaoberal vo svojej múzejnej činnosti a priblížit ním formulované opatrenia a východiská pre múzejnú prax.

\section{Osobnost' Ivana Herčka, vzdela- nie a pracovná činnost’}

Ivan Herčko sa narodil 12. júla 1943 v Ploskom, okres Revúca. Stredoškolské vzdelanie získal na Strednej priemyselnej škole baníckej v Banskej Štiavnici, ktorú ukončil maturitnou skúškou v roku 1961. Pokračoval vysokoškolským štúdiom na Baníckej fakulte Vysokej školy technickej v Košiciach so špecializáciou na banské meračstvo. V rokoch 1969-1971 absolvoval postgraduálne štúdium na Filozofickej fakulte Jana Evangelistu Purkyně v Brne a v roku 1981

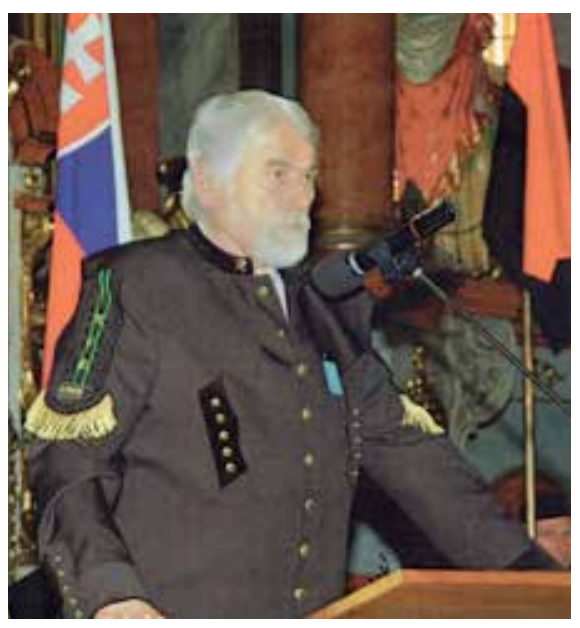

Obr. č. 1: Ivan Herčko (Zdroj: archív autorky).

obhájil vedeckú ašpirantskú prácu na tému História geologických výskumov v banskoštiavnickom rudnom revíri do roku 1918 a získal titul kandidáta historických vied. V roku 2001 sa habilitoval na docenta v odbore banská geológia a geologický prieskum.

Od roku 1966 do roku 1998, s prestávkou v období rokov 1992-1995, pôsobil v Slovenskom banskom múzeu v Banskej Štiavnici, kde prešiel viacerými funkciami až po riaditel’a múzea. V rokoch 1995-1996 bol poverený aj vedením Múzea vo Svätom Antone.

V roku 1998 vedecký pôsobil na Katedre ekomuzeológie Fakulty prírodných vied Univerzity Mateja Bela, v rokoch 2001-2005 bol súčasne vedeckým tajomníkom Ústavu teórie a dejín vied Univerzity Mateja Bela, detašovaného pracoviska v Banskej Štiavnici. Od 1. októbra 2002 do septembra 2005 bol vedúcim Katedry ekomuzeológie tejto univerzity. Od 1. mája 2005 pracoval na Ústave vedy a výskumu Univerzity Mateja Bela v Banskej Bystrici, do konca roku 2007 ako vedúci Oddelenia regionálnych výskumov. Od 1. januára 2008 bol vedecko-výskumným pracovníkom Inštitútu výskumu krajiny a regiónov Ústavu vedy a výskumu a externým vyučujúcim na Katedre environmentálneho manažérstva Fakulty prírodných vied Univerzity Mateja Bela. ${ }^{1}$ Od nástupu do zamestnania v Slovenskom banskom múzeu v roku 1966 sa systematicky zaoberal vedecko-výskumnou činnostou v odbore dejín geológie na Slovensku. Na túto tému spracoval aj svoju kandidátsku prácu. K tejto téme publikoval viacero rozličných štúdií. Za jeho aktívnu publikačnú aktivitu v tejto oblasti bol menovaný za zástupcu Slovenska v Medzinárodnom komitéte pre dejiny geologických vied INHIGEO. Okrem toho zorganizoval na Slovensku dve medzinárodné sympóziá $\mathrm{k}$ dejinám geologických výskumov na území Západných Karpát za účasti zahraničných historikov pre oblast dejín geologických vied. ${ }^{2}$

Bol členom Vedeckej rady Slovenského banského múzea v Banskej Štiavnici a Slovenského technického múzea v Košiciach. Od roku 1999 bol podpredsedom a od roku 2009 zastupujúcim predsedom Komisie pre udelovanie vedeckých

1 DURBÁK, Milan. Doc. Ing. Ivan Herčko, CSc. Personálna bibliografia. Banská Bystrica: Univerzita Mateja Bela, 2003, s. 4.

2 HRONČEK, Peter a Karol WEIS. Významné životné jubileum vedca, univerzitného pedagóga a propagátora vedy doc. Ing. Ivana Herčka, CSc. Quaestiones rerum naturalium, 2014, roč. 1, č. 1, s. 255 . 
titulov $\mathrm{PhD}$. v odbore dejiny vied a techniky pri Historickom ústave Slovenskej akadémie vied v Bratislave. Od júna 2010 bol členom Odborovej komisie pre doktorandské štúdium na Fakulte baníctva, ekológie, riadenia a geotechnológií Technickej Univerzity v Košiciach. ${ }^{3}$

\section{Ivan Herčko a jeho pôsobenie v Slovenskom banskom múzeu v Banskej Štiavnici}

V roku 1966 nastúpil do Slovenského banského múzea v Banskej Štiavnici do funkcie geológa. V roku 1970 sa stal zástupcom riaditela múzea a v roku 1990 riaditelom Slovenského banského múzea.

Za jeho pôsobenia v Slovenskom banskom múzeu v Banskej Štiavnici došlo k postupnej stavebnej obnove objektov Kammerhofu a Starého zámku, kde sa podstatne zmenila organizácia práce a urýchlil sa postup prác na obnove. Náročné a finančne nákladné akcie predstavovala aj údržba objektov múzea. V objektoch Berggerichtu a Klopačky sa v roku 1989 vykonala generálna oprava elektroinštalácie a v roku 1990 aj čiastočná rekonštrukcia elektroinštalácie pre montáž atypických svietidiel v Galérii Jozefa Kollára. Aktualizovala sa expozícia Banského múzea v prírode, sprístupnili sa banské diela na šachte Ondrej. Pokračovalo sa aj na montáži podzemného gápla a vykonala sa expozičná úprava tažných klietok. Zároveň sa v tomto roku priebežne pokračovalo na príprave banícko-technickej expozície v Kammerhofe.

V roku 1991 pod vedením I. Herčka sa pripravila konferencia k 230. výročiu vzniku Baníckej akadémie v Banskej Štiavnici, zorganizoval sa seminár archeológov a iné. V priebehu tohto roka sa pokračovalo v prvostupňovom a druhostupňo-

3 HOCK, Milan. Ivan Herčko - pätdesiatročný. In Zborník slovenského banského múzea XVI. Banská Štiavnica: Slovenské banské múzeum, 1993, s. 247. vom spracovaní zbierok múzea, vykonávala sa fotodokumentácia zbierok, v knižnici bolo spracované vel'ké množstvo kníh, ktoré boli súčasne skatalogizované.

V rámci kultúrno-výchovnej a záujmovej činnosti boli zrealizované rôzne výstavy, besedy a prednášky, vlastivedné a geologické exkurzie, filmové podujatia. Okrem toho múzeum spolupracovalo aj pri zabezpečovaní d’alších podujatí, napríklad pri oslavách Salamandrových dní v Banskej Štiavnici, príprave programu „Zvyky štiavnických akademikov" a d’alšie. V roku 1996 ako riaditel' spolupracoval na vytvorení scenára pre Banské múzeum v prírode, pre inštaláciu expozície uhol’nej techniky na Prachárni. Na Starom zámku v oddelení histórie bol spracovaný scenár pre fajkársku dielňu. $\mathrm{V}$ tomto roku došlo aj k prestahovaniu knižnice do budovy Kammerhofu. Slovenské banské múzeum realizovalo množstvo výstavných podujatí doma i v zahraničí. Uskutočnili sa aj rôzne prednášky, semináre a zrealizovala sa edukačná činnost̉ pre žiakov a študentov.

Budovala sa materiálno-technická základňa múzea v objekte Berggericht a v Kammerhofe, prebehla čiastková oprava striech na budovách Galérie Jozefa Kollára a Kammerhofu. Aj v podzemí Banského múzea $\mathrm{v}$ prírode sa zrealizovali rôzne práce, ako napríklad výmena dosák na podlahe banských chodieb, zámočnícke práce $\mathrm{v}$ podzemí a iné.

Roku 1997 na úseku vedecko-výskumnej činnosti pracovníci múzea pod odborným vedením jeho riaditela, v spolupráci s Banskoštiavnicko-hodrušským baníckym spolkom, spracovali dokument navrhujúci možnosti a potrebu zriadenia vysunutých katedier Univerzity Mateja Bela. Na týchto katedrách by sa vyučovali predmety ako muzeológia, ekológia, konzervátorstvo a ochra- na baníckych a technických pamiatok s akcentom na dejiny baníctva na Slovensku. Táto myšlienka bola zrealizovaná v roku 1998, kedy bola v Banskej Štiavnici zriadená Katedra ekomuzeológie, ako detašované pracovisko Fakulty prírodných vied banskobystrickej Univerzity Mateja Bela.

V oblasti poskytovania odborných informácii sa v priestoroch múzea organizovali viaceré aktivity, najmä prednášky o dejinách baníctva na Slovensku. Zároveň prebehli odborné konzultácie pre študentov vysokých škôl a pre učitelov dejepisu na základných školách.

V čase svojho pôsobenia v Slovenskom banskom múzeu na úseku publikačnej činnosti pripravil Ivan Herčko niekol'ko štúdií uverejnených v Zborníku Slovenského banského múzea. ${ }^{4}$ Spolupracoval tiež s Vedecko-výskumným uhol'ným ústavom v Ostrave-Radvaniciach na príprave rukopisu knižného diela o dejinách uholného baníctva. Významnou mierou sa podielal na spracovávaní portrétov významných osobností slovenskej geológie a baníctva pre monografické, trojzväzkové dielo Priekopníci dejín vied a techniky na Slovensku. ${ }^{5}$ Spolupracoval na spracovávaní hesiel pre Slovenský biografický slovník o múzeách a archívoch na Slovensku. V d’alšej vedecko-výskumnej činnosti treba spomenút jeho účast na archívnom výskume v Štátnom ústrednom banskom archíve v Banskej Štiavnici k problematike dejín baníctva na Slovensku, ktorého výsledky prezentoval nielen v publikačnej činnosti, ale aj na odborných seminároch a konferenciách. ${ }^{6}$

\footnotetext{
4 HERČKO, Ivan. Ústna informácia, poskytnutá dňa 29. 8. 2017 v Banskej Štiavnici.

5 DURBÁK, Milan. Doc. Ing. Ivan Herčko, CSc. Personálna bibliografia. Banská Bystrica: Univerzita Mateja Bela, 2003, s. 12.

6 Výročné správy Slovenského banského múzea v Banskej Štiavnici. Uverejnené so súhlasom riaditela Slovenského banského múzea v Banskej Štiavnici Jozefa Labudu.
} 
Ivan Herčko - riaditel' Múzea vo Svätom Antone

Ivan Herčko v rokoch 1995-1996 pôsobil ako riaditel nielen v Slovenskom banskom múzeu, ale bol poverený aj vedením Múzea vo Svätom Antone, z ktorého bol v tom čase odvolaný bývalý riaditel' Pavol Demko. Tieto dve kumulované funkcie zvládol na vysokej odbornej úrovni, napriek časovej náročnosti. Manažovanie týchto dvoch inštitúcií však nepokladal za zátaž, ale táto práca ho obohacovala, ako nám uviedol pri našich vzájomných rozhovoroch. ${ }^{7}$ Medzi hlavný prínos pôsobenia $\mathrm{v}$ tomto múzeu patrí zriadenie konzervátorskej dielne v kaštieli, ktorá funguje do súčasnosti. I. Herčko sa snažil viesť toto múzeum k systematickej, odbornej činnosti, publikovaniu, organizovaniu rôznych odborných seminárov, výstav, prednášok a iných kultúrnych a vedeckých podujatí.

Dňa 1. 8. 1995 bol I. Herčko poverený vedením Múzea vo Svätom Antone, ktorého v tom čase bol nadriadeným orgánom Ministerstvo kultúry Slovenskej republiky. Súčasne bol aj riaditelom Slovenského banského múzea v Banskej Štiavnici. „Skíbit tieto dve funkcie bolo dost' náročné nielen na manažovanie týchto dvoch inštitúcii, ale aj rozvrhnút si čas, na kvalitné vypracovanie koncepcie rozvoja tohto múzea. Ako prvú úlohu som si dal zriadit'v tomto múzeu konzervátorskú dielňu. Zo Slovenského banského múzea som do Antolského múzea presunul 3 konzervátorky, ktoré tam vykonávali prax. Ďalšou mojou prioritou $v$ tomto múzeum, bolo skvalitnenie evidencie dokumentácie a celkového spracovania zbierkového fondu. Zmenil sa aj systém ochrany objektu, čím sa zlepšila aj ochrana zbierkových predmetov pred odcudzením. Jeden rok som 3 dni $v$ týždni pracoval $v$ Slovenskom banskom múzeu a 2 dni v Antolskom múzeu. Cez víkendy som sa zúčast-

7 Rozhovory sa uskutočnili v roku 2017 v Banskej Štiavnici. ňoval na rozličných akciách, ktoré sme organizovali, alebo som pozvaný. Bol to velmi hektický rok, ale mám nezabudnutel'né spomienky na prácu, ktorú som miloval.“"

V roku 1995 prebehli v Múzeu v Antole aj rôzne akcie, ako napríklad „Okresná chovatel'ská prehliadka polovníckych trofejí ulovených v sezóne 1994/1995“, alebo podujatie s názvom „Príbeh o zemi a človeku“ v spolupráci s Domovom pre postihnuté deti v Novej Bani. Pri príležitosti Medzinárodného dňa múzeí bola v múzeu otvorená výstava porcelánu a keramiky z depozitára múzea s názvom „Krehká krása“. V júli 1996 bola pod vedením nového riaditela realizované nové podujatie „Nočná prehliadka“, kde sa múzeum snažilo návštevníkom priblížit informácie zo života pôvodných majitelov kaštiel'a. Na nádvorí kaštiela súbežne s nočnou prehliadkou účinkovalo divadlo Shanti z Prievidze. Koncom roku boli realizované $\mathrm{v}$ múzeu d’alšie výstavy, ako „Výstava na záchranu kamzíka tatranského" a v predvianočnom čase múzeum pripravilo akciu „Rezbári Štiavnicka“, bola to výstava drevených betlehemov od rezbárov z Antola. Konali sa aj každoročné pol’ovnícke slávnosti „Dni svätého Huberta“ s typickým programom pre polovníkov. ${ }^{9}$

\section{V roku 1996 sa v Múzeu Antol} v spolupráci so Slovenským polovníckym zväzom a Klubom histórie slovenského pol’ovníctva zrealizoval seminár s názvom „Z histórie polovníctva a rybárstva na Slovensku“, ktorý nadväzoval na výstavu, ktorá sa realizovala $\mathrm{v}$ tomto múzeu s názvom „100 rokov vzniku štátnych lesov". Pod vedením I. Herčka odborní pracovníci múzea pripravili popisky a vstupný text $\mathrm{k}$ výstave v Šahách „Polovníctvo v regióne

\footnotetext{
8 HERČKO, Ivan. Ústna informácia, poskytnutá dňa 29. 8. 2017 v Banskej Štiavnici.

9 Výročná správa Antolského múzea v roku 1995 Uverejnené so súhlasom bývalého riaditela Múzea vo Svätom Antone Mariana Číža.
}

Hont“. V meste Greillensteine v Rakúsku múzeum pripravilo výstavu „Habsburgovci v zbierkach Antolského múzea" a v Mad’arsku v Budapešti múzeum spolupracovalo s Mad’arským pol'nohospodárskym múzeom na výstave „Kamzík SOS“. V tomto roku bolo múzeum začlenené pod Podsitnianske kultúrne centrum v Banskej Štiavnici a novým riaditelom múzea sa stal Marian Číž. ${ }^{10}$

\section{Pôsobenie Ivana Herčka v Ban- skoštiavnicko-hodrušskom baníc- kom spolku}

Ivan Herčko bol zakladajúcim členom Banskoštiavnicko-hodrušského baníckeho spolku, neskôr aj členom jeho riadiaceho výboru a zároveň dlhoročný predseda publikačnej sekcie. Banskoštiavnicko-hodrušský banícky spolok vznikol 19. 12. 1992 transformáciou Základnej organizácie Slovenskej vedecko-technickej spoločnosti pri Rudných baniach závod Banská Štiavnica. Spolok svojimi cielmi a činnostou nadviazal na tradíciu Banskoštiavnického zdravotníckeho a prírodovedného spolku, založeného ešte v roku 1870 s poslaním obnovenia, udržiavania a rozvíjania tradície baníckych zvykov. Medzi banícke zvyky sa zarad’oval hlavne šachtág so skokom cez kožu, banícke plesy, organizovanie stretnutí členov za účelom rozvíjania poznatkov o baníctve a s baníctvom súvisiacich odvetví. Spolok už v deň ustanovujúceho valného zhromaždenia uskutočnil prvý obnovený banícky šachtág mimo akademickej a školskej pôdy a následne aj reprezentačný banícky ples. ${ }^{11}$

V roku 1998 sa I. Herčko zaslúžil o začiatok organizovania malých šachtágov so skokom cez kožu pri životných jubileách členov spolku

10 Výročná správa Antolského múzea v roku 1996.

11 DURBÁK, Milan. Almanach Banskoštiavnicko-hodrušského baníckeho spolku. Banská Štiavnica: Banskoštiavnicko-hodrušský banícky spolok, 2012, s. 13. 
a v spolupráci s Mestom Banská Štiavnica aj pri významných návštevách mesta, akými boli návšteva monackého princa Alberta $\mathrm{v}$ roku 2002, prezidenta Slovenskej republiky Rudolfa Schustera v roku 2003, prezidenta Slovenskej republiky Ivana Gašparoviča v roku 2006 a d’alších významných osobností. $\mathrm{V}$ tomto roku sa začali organizovat aj stretnutia bývalých zamestnancov Rudných baní, závod Banská Štiavnica. Členovia spolku zabezpečujú aj humanitárnu činnost', zabezpečovaním štafáže pri odprevádzaní členov spolku a bývalých baníkov na ich poslednej ceste.

V roku 1999 začal banícky spolok, hlavne jeho riadiaci výbor, ktorého bol I. Herčko členom iniciovat osadzovanie pamätných tabúl dejatelom baníctva a geológie, ako aj pamätné tabule na označenie budov a banských diel.

V roku 2001 bolo založené podujatie „Jozefovské stretnutie“, počas ktorého bola v Baníckej krčme pri štôlni Glanzenberg osadená soška sv. Jozefa, podujatie sa uskutočňuje každoročne dodnes. Rok 2001 sa stal významným aj podpísaním Deklarácie pokračovatelov duchovného dedičstva Baníckej akadémie, o ktorú sa významne zaslúžil I. Herčko a vtedajší primátor Banskej Štiavnice Marián Lichner. Spolok každoročne organizoval pre svojich členov a aj verejnost' viacero podujatí, napríklad reprezentačné banícke plesy. Ďalšími významnými podujatiami sú podujatia venované osobnosti štiavnického Nácka, „Náckova Štiavnica“, zameraná na prezentáciu náckovských špásov a príbehov v štiavnickom dialekte a „Náckov pochod“, uskutočňovaný z príležitosti mena Ignác (po štiavnicky „Nácko“). Najvýznamnejšími sú však banícke šachtágy, spojené $\mathrm{s}$ prijímaním osôb do baníckeho stavu „skokom cez kožu“, hlavný šachtág sa uskutočňuje pri príležitosti Salamandrových dní.
V roku 2002 bol banícky spolok zaregistrovaný ako samostatná právnická osoba, občianske združenie. V roku 2003 vydal banícky spolok viaceré publikácie, ktoré sa spájali zo životom baníkov z Banskej Štiavnice. Od roku 2005 spolok organizuje humoristické podujatie „Náckova Štiavnica“, zamerané na prezentáciu vtipov a príbehov v štiavnickom dialekte. Z iniciatívy Banskoštiavnicko-hodrušského baníckeho spolku došlo $\mathrm{k}$ založeniu Združenia baníckych spolkov a cechov Slovenska so sídlom v Banskej Štiavnici, inštitúcie zastrešujúcej banícke spolky na celoštátnej úrovni. Spolok poskytol pomoc pri zakladaní skoro všetkým baníckym spolkom na Slovensku a zabezpečoval im aj prezentáciu šachtágov, napríklad to bolo pre Malokarpatský banícky spolok v Pezinku a pre Banícke bratstvo Herrengrund v Španej Doline, ale aj pre Handlovský banícky spolok. ${ }^{12}$ Vedecký prínos Ivana Herčka bol v týchto odborných činnostiach v Banskoštiavnickom-hodrušskom spolku klúčový. ${ }^{13}$

\section{Pedagogická činnost’}

Pedagogická činnost̉ Ivana Herčka sa začala rozvíjat ešte $\mathrm{v}$ roku 1995, kedy vypracoval model výučby muzeológie v Banskej Štiavnici. Spolu s prodekanom Fakulty prírodných vied Hubertom Hilbertom a Zbyňkom Stránskym tento projekt prepracovali do detailov a v roku 1998 sa im podarilo úspešne zriadit Katedru ekomuzeológie v Banskej Štiavnici, ako detašované pracovisko Fakulty prírodných vied Univerzity Mateja Bela v Banskej Bystrici. Katedra ekomuzeológie

12 KAŇA, Richard. Už na baňu klopajú. Banská Štiavnica: Banskoštiavnicko-hodrušský banícky spolok, 2012, s. 8.

13 „Medzi hlavný vedecký prínos Ivana Herčka pre náš spolok bola jeho odborná spôsobilost' organizovat' rôzne konferencie, semináre, tematické posedenia, prednášky s baníckym zameraním. Jeho vedecký rozhl'ad bol pre náš spolok nenahraditel'ný a táto významná osobnost' nám bude vel'mi chýbat'." KAŇA, Richard. Predseda Banskoštiavnicko-hodrušského baníckeho spolku. Ústna informácia. bola zriadená pre potreby pracovníkov múzeí, galérií a príbuzných inštitúcii na doplnenie si muzeologického vzdelania. ${ }^{14}$ „Výučba prebiehala na detašovanom pracovisku $v$ Banskej Štiavnici vo formách štúdia denného aj dištančného. Ako prvé som zostavil anotácie predmetov s použitím relevantnej literatúry $k$ týmto témam. Čo sa týka predmetu Špecializovaná muzeológia, zameral som sa na oboznámenie študentov sa $s$ prínosom ponímania tohto predmetu, preverovania jeho teoretickej časti $v$ každodennej praxi. Zdôrazňoval som prepojenie špecializovanej muzeológie v spolupráci s inými vednými disciplínami, napríklad archivistika, informatika a iné. Obsahovú náplň predmetu som rozdelil na niekol'ko časti. Úvodné prednášky boli zamerané na osvojenie si teoretických základov špecializovanej muzeológie a predstavenie špeciálnych muzeologických metód $v$ pramenných odboroch aplikovaných $v$ múzejnej praxi. $V$ závere prednášok som predstavil uplatnenie múzejnej technológie a muzeologických zámerov v múzejníctve. Študenti si odnášali poznatky, ktoré budú môct' neskôr zrealizovat' pri práci v múzeu, alebo príbuzných vedných odboroch."15

Následne spolu s profesorom Ottom Tomečkom ako rektorom univerzity pripravili d’alšie detašované pracovisko - Ústav teórie a dejín vied, ktorý bol zriadený v 2001. Koncepcia Ústavu teórie a dejín vied bola zameraná na štúdium problematiky rozvoja slovenskej vedy v poslednej štvrtine 19. storočia a začiatkom 20. storočia, zvlášt dejín prírodných vied na Slovensku a muzeológie. I. Herčko bol vymenovaný za vedeckého tajomníka tohto ústavu. Ústav sa aj jeho zásluhou významnou mierou podielal na d’alšom

\footnotetext{
14 HRONČEK, Peter a Karol WEIS. Významné životné jubileum vedca, univerzitného pedagóga a propagátora vedy doc. Ing. Ivana Herčka, CSc. Quaestiones rerum naturalium, 2014, roč. 1, č. 1 , s. 256.

15 HERČKO, Ivan. Ústna informácia, poskytnutá
} dňa 16. 10. 2017 v Banskej Štiavnici. 
rozvoji poznatkov v odbore dejín prírodných vied a techniky. Postupne bolo dobudované dokumentačné centrum, rukopisný archív, fotoarchív a odborná knižnica pre výchovu poslucháčov tejto katedry.

V rámci spolupráce s Fakultou prírodných vied Univerzity Mateja Bela, Ústav teórie a dejín vied zabezpečoval vysokoškolskú výchovu pre rôzne študijné odbory. $S$ obrovským zanietením presadzoval navrátenie vysokoškolského vzdelávania do Banskej Štiavnice. Hlavne jeho pričinením sa $\mathrm{v}$ meste $\mathrm{s}$ bohatými akademickými tradíciami etablovala Fakulta prírodných vied, Katedra ekomuzeológie Univerzity Matej Bela. Najdôležitejšou úlohou Ústavu teórie a dejín vied Univerzity Mateja Bela ako vedecko-dokumentačného centra malo byt vybudovanie informačnej databázy na základe štúdia archívnych a literárnych prameňov, sústred’ovania písomných pozostalostí po významných odborníkoch $\mathrm{v}$ rôznych oblastiach dejín vedy a techniky. ${ }^{16}$

Výber z publikačnej činnosti Ivana Herčka a významné ocenenia

Ivan Herčko publikoval priebežne od roku 1968 do roku 2017, čo je skoro neuveritelných 50 rokov. Napísal 15 monografií, okolo 150 štúdií a stoviek odborných a popularizačných prác publikovaných doma i v zahraničí, sedem študijných textov z muzeológie a bol spoluautorom viacerých knižných diel.

Za túto publikačnú činnost̉ získal aj množstvo ocenení, medzi tie najvýznamnejšie bezpochyby patrila publikácia Minerály Slovenska (1984), ktorá bola Slovenským literárnym fondom ocenená prémiou ako najlepšia publikácia v rámci technickej a prírodovednej literatúry za rok 1984 a Európska federácia pre mineralógiu a paleontológiu

16 CEJPEK, Kamil. Kto bol Otto Tomeček? Banská Bystrica: Univerzita Mateja Bela, 2009, s. 53-54. v Bologni ju ocenila Zlatým diplomom. Prestížne ocenenie získalo aj dielo Banícka a lesnícka akadémie slovom a obrazom (2008), bola mu udelená cena Literárneho fondu Slovenskej republiky v kategórii spoločenských vied.

Ako spoluautor sa podielal spolu s jeho kolegom z Univerzity Mateja Bela Ottom Tomečkom na publikácii Chémia a mineralógia na Baníckej akadémii $v$ Banskej Štiavnici (2001), v roku 2002 získali prémiu za vedeckú a odbornú literatúru za rok 2001 v kategórii prírodných a technických vied. V septembri 2011 udelil Ivanovi Herčkovi minister hospodárstva Slovenskej republiky Juraj Miškov čestný odznak ,ZZa udržiavanie tradícií" za jeho publikačnú činnosṫ zameranú na históriu baníctva a geológie a osobitne za históriu Baníckej a lesníckej akadémie. $^{17}$

Po jeho smrti bol ocenený in memoriam za dlhodobo kvalitné pracovné výsledky počas pôsobenia v Slovenskom banskom múzeu, za prínos k slovenskej muzeológii a propagáciu montanistiky. $\mathrm{Pa}$ mätnú medailu si prevzal jeho syn Adrián Herčko z rúk predsedníčky Zväzu múzeí na Slovensku na 28. valnom zhromaždení, ktoré sa uskutočnilo dňa 3. 5. 2018 vo Velkej sále Múzea Slovenského národného povstania v Banskej Bystrici.

Krátko pred smrtou Ivana Herčka (25. 12. 2017) som s ním uskutočnila niekol'ko rozhovorov. Tento dôležitý pramenný materiál nám poskytol autor aj ked jeho zdravotný stav bol vel'mi zhoršený, ale aj napriek tomu o svojich dielach rozprával s obrovským nadšením. Ivan Herčko tu ozrejmoval, za akých okolnosti monografie a iná jeho publikačná činnost' vznikala, čo ho

17 HRONČEK, Peter a Karol WEIS. Významné životné jubileum vedca, univerzitného pedagóga a propagátora vedy doc. Ing. Ivana Herčka, CSc. Quaestiones rerum naturalium, 2014, roč. 1, č. 1, s. 256-262. viedlo $\mathrm{k}$ ich napísaniu, prípadne iné podstatné informácie $\mathrm{k}$ jeho výberovej bibliografii, klúčových publikácií, z jeho vlastného pohladu.

\section{Monografie}

HERČKO, Ivan. Geologická expozícia $S B M v$ Banskej Štiavnici - Sprievodca. Bratislava: Vydavatel'stvo L’ud, 1968.

121 s. $^{18}$

HERČKO, Ivan. $Z$ dejín geologických vied na Slovensku. Martin: Vydavatel'stvo Osveta, 1981, $235 \mathrm{~s}$.

HERČKO, Ivan. Minerály Slovenska.

Martin: Vydavatel'stvo Osveta, 1984.

321 s. $^{19}$

HERČKO, Ivan. Banská Štiavnica na Listine svetového a kultúrneho dedičstva UNESCO. Banská Bystrica: Erland, 1995. $185 \mathrm{s.}^{20}$

HERČKO, Ivan. Osobnosti Banskej Štiavnice a okolia. Banská Štiavnica: Slovenské banské múzeum, 1996. $236 \mathrm{~s}$. HERČKO, Ivan. Slovenské banské múzeum, minulost', súčasnost' a perspektívy. Banská Štiavnica: Slovenské banské múzeum, 1996. $187 \mathrm{~s}$.

HERČKO, Ivan. Vodné nádrže v okolí Banskej Štiavnice. Banská Štiavnica: Slovenské banské múzeum, 1996. 247 s. $^{21}$

HERČKO, Ivan. Zberatelstvo minerálov a ich múzejná prezentácia. Banská Bys-

18 Publikáciu autor vydal na začiatku jeho pôsobenia v Slovenskom Banskom múzeu v Banskej Štiavnici. Múzeum vtedy potrebovalo sprievodnú publikáciu pre geologickú expozíciu a Ivan Herčko ako absolvent Baníckej fakulty mal k tejto téme vel'mi blízky vztah.

19 Sám autor bol mimoriadne pyšný na túto monografiu, ktorá komplexne prezentovala minerály nachádzajúce sa na území Slovenska. Publikácia bola ocenená Slovenským literárnym fondom ako najlepšia publikácia v rámci technickej a prírodovednej literatúry a Európska federácia pre mineralógiu a paleontológiu v Bologni ju ocenila Zlatým diplomom.

20 Dielo bolo vydané v spolupráci so Slovenským banským múzeom v rámci edičnej a publikačnej činnosti múzea v náklade 1320 kusov. Banská Štiavnica bola v roku 1993 zapísaná na Listinu svetového a kultúrneho dedičstva UNESCO a pri tejto príležitosti sa rozhodol vydat toto dielo nielen pre návštevníkov múzea, ale aj pre širokú verejnost?.

21 V tomto čase Ivan Herčko pôsobil v Slovenskom banskom múzeu ako riaditel' a aj ked' bol plne zaneprázdnený vedením tejto inštitúcie, našiel si čas na napísanie týchto titulov. Vyšli v rôznom náklade, záležalo aj na finančnej situácii múzea a nájdení sponzorov. 
trica: Univerzita Mateja Bela, 2002.

275 s. $^{22}$

HERČKO, Ivan. Banícka a lesnícka akadémia slovom a obrazom. Banská Bystrica: Univerzita Mateja Bela, Ústav vedy a výskumu, 2008. 286 s. $^{23}$

HERČKO, Ivan. Banská Štiavnica na starých pohl'adniciach. Bratislava: Dajama, 2008. $95 \mathrm{~s}$.

HERČKO, Ivan. Banská Štiavnica na starých pohladniciach II. Bratislava: Dajama, 2017. 96 s. $^{24}$

HERČKO, Ivan. Dejiny múzejnej kultúry na Slovensku. Banská Bystrica: Univerzita Mateja Bela, Ústav vedy a výskumu, Fakulta prírodných vied, 2009.

$306 \mathrm{~s}$.

HERČKO, Ivan. Stručné dejiny Baníckej a lesníckej akadémie v Banskej Štiavnici. Banská Bystrica: Ústav vedy a výsku$\mathrm{mu}, 2009.357 \mathrm{~s}$.

HERČKO, Ivan. Stredné Pohronie na starých pohl'adniciach. Bratislava: Dajama, 2010. $213 \mathrm{~s}$.

Študijné texty pre Katedru muzeológie Univerzity Mateja Bela

HERČKO, Ivan. Všeobecná geológia. Skriptum. Banská Bystrica: Univerzita Mateja Bela, Fakulta prírodných vied, Katedra krajinnej ekológie, 2000.

$101 \mathrm{~s}$.

HERČKO, Ivan. Mineralógia a petrológia. Skriptum. Banská Bystrica: Univerzita Mateja Bela, Fakulta prírodných vied, Katedra krajinnej ekológie, 2000. $121 \mathrm{~s}$.

22 Zberatel’stvo minerálov bola autorova záluba už od detstva. Doma vlastnil vel'kú zbierku minerálov z celého sveta. Značnú časṫ zo svojej zbierky daroval nielen Slovenskému banskému múzeu, ale aj iným múzeám na Slovensku.

23 Rovnako ako publikácia Minerály Slovenska, aj táto získala ocenenie - prémiu Literárneho fondu za rok 2008 v kategórii spoločenských vied. To už Ivan Herčko pôsobil na Univerzite Mateja Bela ako pedagogický a výskumný pracovník a cena mu bola odovzdaná v Pezinku za účasti primátora mesta.

24 V rokoch 2008 a 2017 vydal d’alšie monografie v spolupráci s vydavatel'stvom Dajama. Ako zanietený zberatel' pohl'adníc mal vo svojom súkromnom archíve nielen pohl'adnice Banskej Štiavnice, ale aj viacerých Slovenských miest a obcí. Rozhodol sa ich publikovat’ v týchto monografiách, ktoré sa snažia pútavou formou priblížit život v meste Banská Štiavnica a zachytit najvýznamnejšie dominanty tohto obdobia.
HERČKO, Ivan. Muzealizácia vedy a techniky. Skriptum. Banská Bystrica: Univerzita Mateja Bela, Fakulta prírodných vied, Katedra ekomuzeológie, 2002. $170 \mathrm{~s}$.

HERČKO, Ivan. Múzejné výstavníctvo. Skriptum. Banská Bystrica: Univerzita Mateja Bela, Fakulta prírodných vied, Katedra ekomuzeológie, 2003. 145 s. HERČKO, Ivan. Teoretická muzealógia selekcia. Skriptum. Banská Bystrica: Univerzita Mateja Bela, Fakulta prírodných vied, Katedra ekomuzeológie, 2003. $117 \mathrm{~s}$

HERČKO, Ivan. Muzealizácia spoločnosti. Skriptum. Banská Bystrica: Univerzita Mateja Bela, Fakulta prírodných vied, Katedra ekomuzeológie, 2003. $169 \mathrm{~s}$.

HERČKO, Ivan. Mediácia spoločnosti. Skriptum. Banská Bystrica: Univerzita Mateja Bela, Fakulta prírodných vied, Katedra ekomuzeológie, 2003. 103 s.

\section{Záver}

Ivana Herčka môžeme právom zaradit medzi gestoroch slovenskej muzeológie. Bol vel'kým prínosom nielen na poli muzeológie, ale aj dejín vedy a techniky, baníctva, mineralógie a iných vedných disciplín. Bol to vedecký pracovník, univerzitný pedagóg, propagátor vedy a techniky a bývalý riaditel' Slovenského banského múzea v Banskej Štiavnici.

Mojou snahou bolo zdokumentovat nesporný prínos tejto významnej osobnosti, ktorá počas svojho života posunula hranicu poznania $\mathrm{v}$ týchto vedných odborov o výrazný krok vpred. Zosumarizoval a napísal 7 študijných textov pre študentov muzeológie a geológie na Univerzite Mateja Bela v Banskej Bystrici, bol gestor viacerých študijných odborov. Táto jedinečná a významná osobnost' mala nenahraditel'né zastúpenie pre poznanie muzeológie ako vedy a toto posolstvo šíril aj v mysliach svojich študentov. Patril medzi uznávané vedecké osobnosti na Slovensku, požíval uznanie nie- len medzi svojimi študentmi, ale aj kolegami, priatel'mi a známymi.

I. Herčko bol vášnivý zberatel' minerálov, ktoré neskôr venoval Slovenskému banskému múzeu. Celým svojím životom a prácou prispel k obohacovaniu a rozšíreniu zbierkového fondu nielen Slovenského banského múzea, ale aj iných múzeí na Slovensku.

Je mi nesmiernou ctou, že som mohla osobne poznat' Ivana Herčka, obdivovala som jeho ohromné vedomosti vo vedeckej oblasti. Pri rozhovoroch s ním som mala pocit, že sa rozprávam so živou encyklopédiou vedomostí. Mal vynikajúcu pamät a rád mi poskytol všetky informácie, aj ked’ bo zdravotne tažko chorý a len s námahou už dokázal rozprávat'. Verím, že som pootvorila cestu $\mathrm{k}$ poznaniu tohto skromného, jedinečného a vzácneho človeka, ktorý mal vel'kú zásluhu na formovaní sa muzeológie ako vedy a zanechal nezmazatelnú stopu nielen v oblasti muzeológie, ale aj geológie, mineralógie, dejín vedy a techniky na Slovensku a v zahraničí.

Na záver môžem konštatovat', že muzeológia sa aj jeho zásluhou postupne etablovala na pozíciu starších vedných odborov a zaznamenala nebývalý vzostup. Na základe jeho obetavej práce bol jeho prínos pre muzeológiu ako vedu nenahraditel’ný. V roku 2010 tažko ochorel, utrpel mozgovú príhodu a zle znášal fakt, že ostal pripútaný na lôžko. Zomrel 25. 12. 2017 vo svojom byte v Banskej Štiavnici. Čest' jeho pamiatke. „ZDAR BOH!“

\section{POUŽITÉ ARCHÍVNE PRAMENE A LITERATÚRA:}

Archív Slovenského banského múzea v Banskej Štiavnici. Dokumentačné oddelenie. Výročné správy SBM za roky 1990, 1991, 1992, 1996, 1997, 1998 
Archív Múzea vo Svätom Antone. Dokumentačné oddelenie. Výročné správy za roky 1995, 1996.

CEJPEK, Kamil (ed.). Kto bol Otto Tomeček? Banská Bystrica: Univerzita Mateja Bela, 2009. 115 s. ISBN 978-80-8083-900-0.

DURBÁK, Milan. Doc. Ing. Ivan Herčko, CSc. Personálna bibliografia. Banská Bystrica: Univerzita Mateja Bela, 2003. 43 s.

DURBÁK, Milan. Almanach Banskoštiavnicko-hodrušského baníckeho spolku. Banská Štiavnica: Banskoštiavnicko-hodrušský banícky spolok, 2012. 125 s. ISBN 978-80-9708-511-3.
HOCK, Milan. Ivan Herčko - pätdesiatročný. In Zborník slovenského banského múzea XVI. Banská Štiavnica: Slovenské banské múzeum, 1993, s. 247-249. ISBN 80901392-3-X

HRONČEK, Peter a Karol WEIS. Významné životné jubileum vedca, univerzitného pedagóga a propagátora vedy doc. Ing. Ivana Herčka, CSc. Quaestiones rerum naturalium, 2014, roč. 1, č. 1, s. 253-266. ISSN 1339-7907.

KAŇA, Richard. Už na baňu klopajú. Banská Štiavnica: Banskoštiavnicko-hodrušský banícky spolok, 2012. 102 s. ISBN 978-80-9708-511-7.
WEIS, Karol. Slávnostná prezentácia a krst novej publikácie o Baníckej akadémii v Banskej Štiavnici za účasti prezidenta SR. Quaestionesrerumnaturalium, 2014, roč. 1, č. 1, s. 270-271. ISSN 1339-7907.

\author{
ELENA HEGYI \\ doktorandská študentka, \\ Katedra histórie, \\ Filozofická fakulta, \\ Univerzita Konštantína Filozofa \\ v Nitre, Slovenská republika
}

PRÍLOHA Č. 1:

Ivan Herčko v spomienkach Jozefa Čárskeho, emeritného profesora Univerzity Komenského v Bratislave (Zdroj: ČÁRSKY, Jozef. E-mailová komunikácia dña 25. 9. 2018.)

Ivan Herčko bol aktívnym členom viacerých odborných spoločností, vrátane Slovenskej chemickej spoločnosti, odbornej skupiny pre históriu chémie. „S docentom Ing. Ivanom Herčkom, CSc. som sa prvý krát stretol v r. 1980, v súvislosti s prípravou Zjazdu slovenských a českých chemikov, ktorý sa konal v roku 1981 v Banskej Bystrici. Ako člen organizačného výboru som vtedy zabezpečoval odborný program $v$ sekcii História chémie. Na stretnutiach výboru Slovenskej chemickej spoločnosti, najmä však $v$ kontakte s predsedom organizačného výboru zjazdu prof. RNDr. Ottom Tomečkom, CSc., vtedajším rektorom Univerzity Mateja Bela $v$ Banskej Bystrici a vedúcim Katedry chémie Pedagogickej fakulty tejto univerzity, sa nastolovala požiadavka prepojenia zjazdu s Banskou Štiavnicou, s ciel'om prezentovat' históriu jej slávnej Baníckej a lesníckej akadémie. Naplnenie tejto požiadavky si vyžiadalo osobný kontakt $s$ riaditel'om tamojšej Chemickej priemyslovky, sídliacej $v$ historickej budove akadémie, Ing. Jozefom Benckom, CSc. Pán riaditel' bol vel'mi ústretový a okrem vlastnej účasti na realizácii predmetného zámeru odporúčal a aj zabezpečil kontakt s Baníckym múzeom a jeho riaditelom, erudovaným znalcom histórie Banskej Štiavnice Ing. Ivanom Herčkom.
Už prvé naše stretnutie bolo mimoriadne srdečné a spontánne. Hned' sa dalo vycítit', že ho velmi oslovil záujem o prepojenie programu pripravovaného chemického zjazdu s Banskou Štiavnicou. $V$ útulnej pracovni $v$ priestoroch historickej budovy múzea sme potom dlho živo diskutovali o bohatej histórii mesta a štiavnickej akadémie. Zakrátko sme si nielen potykali (s kalíškom domácej rožovky), ale získal som pocit úprimnosti a spolupatričnosti. Nielen to, začala aj naša efektívna odborná spolupráca, ktorá v opakovaných osobných stretnutiach vyústila do konkretizácie programu pripravovaného chemického zjazdu. Pre účastníkov zorganizoval zaujímavé poznávacie exkurzie do historických objektov Banskej Štiavnice. Vyvrcholením jeho účasti bola oficiálna prezentácia reprezentatívneho literárneho diela: Chémia a mineralógia na Baníckej a lesníckej akadémii $v$ Banskej Štiavnici, autorov Ivana Herčka a Otta Tomečka. Treba pripomenút, že autori museli vyvinút mimoriadne úsilie, aby sa stihlo vydanie knihy do termínu zjazdu.

Naše priatel'ské aj odborné kontakty pokračovali samozrejme d'alej. S potešením som sa aktívne zúčastňoval na odborných podujatiach, ktoré organizoval pán docent pod hlavičkou jeho Ústavu vedy a výskumu Univerzity Mateja Bela $v$ Banskej Štiavnici. Bohužial', vel'mi smutný som odchádzal, ked' som ho navštívil $v$ Národnom rehabilitačnom ústave $v$ Kováčovej, kde sa podroboval liečbe po cievnej mozgovej príhode, ktorá mu zabránila pokračovat’ $v$ intenzívnej práci. Obdivoval som ho, ked' sa neskôr na invalidnom vozíku s podlomeným zdravím zúčastnil prednáškou na seminári v Banskej Štiavnici, ktorý bol venovaný profesorovi Baníckej a lesníckej akadémie Antonovi Leopoldovi Ruprechtovi. A vel'mi som l'utoval, že nemohol byt' prítomný na neskoršom odhal'ovaní pamätnej tabule tomuto velikánovi európskej chémie (zaradeného do zoznamu 100 najvýznačnejších európskych chemikov) v nádvorí Belházyovskeho domu.

Zostávajú už len spomienky na milého priatel'a, vzácneho človeka a pracovitého mimoriadneho odborníka, docenta Ing. Ivana Herčka, obdiv a pocit vd’aky za spolu prežité krásne chvíle, ktoré časom tiež pominú. Natrvalo však zostane jeho dielo, ktorým tak významne prispel do kultúrneho dedičstva Slovenska.“ 